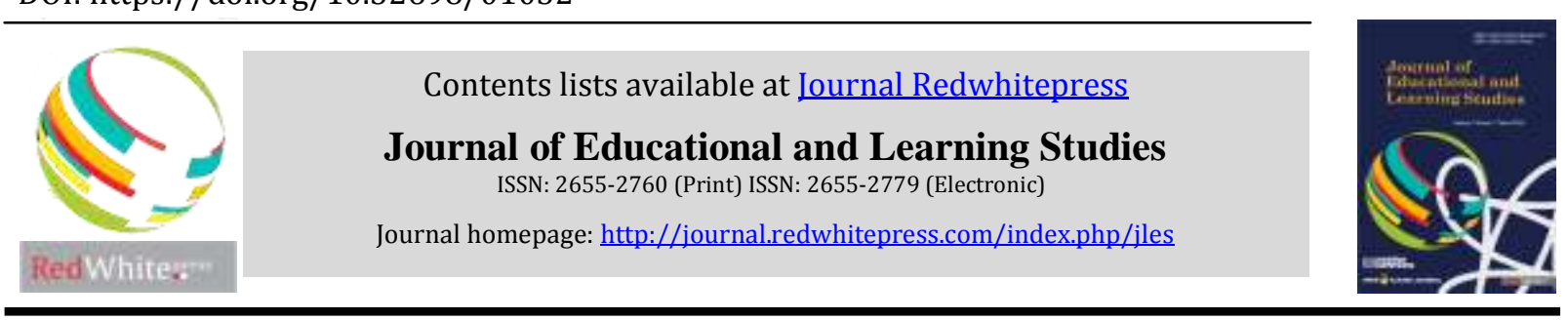

\title{
Development of mathematics learning module based on mind- mapping on opportunity materials
}

\author{
Trisna Rukhmana ${ }^{1}$, Loria Wahyuni ${ }^{2}$ \\ STKIP Muhammadiyah Sungai Penuh
}

\begin{tabular}{l} 
Article Info \\
\hline Article history: \\
Received Aug $24^{\text {th }}, 2020$ \\
Revised Sep $21^{\text {th }}, 2020$ \\
Accepted Oct $12^{\text {th }}, 2020$ \\
\hline
\end{tabular}

\section{Keyword:}

Module

Mind-Mapping based

Mathematics

Development

Opportunities

\begin{abstract}
Based on the results of observations made at SMA N 5 Sungai Penuh known that in the mathematics learning process students do not understand the learning material well, the ability of students to develop material concepts and solve problems in the form of practice questions given by the teacher is still lacking, students are lacking of self-confidence to ask if there is material that has not been understood, students also cannot develop their thinking ideas creatively. This means that the ability to think creatively and critically of students has not developed optimally. The specific purpose of this research is to develop and produce teaching materials in the form of mind mapping-based modules for learning mathematics, which are valid, practical and effective and can increase students' motivation, activities and learning outcomes, especially in the material opportunities. This development research consists of four stages, namely; the define stage, the design stage, the develop stage and the disseminate stage. The validation results with the valid category indicated by an average value of $76 \%$. The practicality results with the practical category are shown by an average value of $75.3 \%$. Effectiveness results with the effective category in terms of the aspects of activity, student motivation, and from the aspect of achievement of learning outcomes.
\end{abstract}

(C) 2020 The Authors. Published by Redwhitepress.

This is an open access article under the CC BY-NC-SA license (https://creativecommons.org/licenses/by-nc-sa/4.0/

\section{Corresponding Author:}

Trisna Rukhmana

STKIP Muhammadiyah Sungai Penuh

Email: trisnarukhmana29@gmail.com

\section{Introduction}

Referring to the National Education System Law no. 20 of 2003 stated that education is a conscious and planned effort to realize an active learning process in developing his potential to have religious spiritual strength, self-control, personality, intelligence, noble character and skills needed by themselves, society, nation and state. One of the conscious efforts made is by developing teaching materials. According to Panen (2011) teaching materials are materials or subject matter that is systematically arranged which are used by teachers and students in the learning process (Andi, 2011). According to the Directorate of Senior High School Development (2010), the definition of teaching materials is any form of material used to assist teachers in carrying out teaching and learning activities. The material in question can be in the form of written material or unwritten material. Based on these definitions, it can be concluded that teaching materials are a learning 
component used by teachers as learning materials for students and assisting teachers in carrying out teaching and learning activities in the classroom. Types of Teaching Materials Types of teaching materials are divided into several grouping criteria. According to Koesnandar (2018), the types of teaching materials based on the subject consist of two types, namely: (a) teaching materials that are deliberately designed for learning, such as books, handouts, worksheets and modules; (b) teaching materials that are not designed but can be used for learning, for example clippings, newspapers, films, advertisements or news. Koesnandar also stated that when viewed from its function, the teaching materials designed consist of three groups, namely presentation materials, reference materials, and independent study materials. Based on the technology used, the Directorate of Senior High School Development (2010) classifies teaching materials into four categories, namely printed teaching materials, including handouts, books, modules, student activity sheets, brochures, leaflets, wall charts, photos / pictures, and model / mockup. Hearing teaching materials (audio) include cassettes, radios, LPs, and audio compact disks, as well as audio-visual teaching materials such as video compact disks and films. According to Iis Aprinawati (2018), some students have difficulty concentrating when doing assignments. This happens because the notes or memories are not organized. For that, we need a tool to help the brain think regularly.

The brain remembers information in the form of pictures, symbols, forms, sounds, music, and feelings. The brain stores information with patterns and associations like trees with their branches and twigs. The brain does not store information word for word or column by column in neat rows as we put out in language. In order to quickly recall what we have learned it is best to mimic the workings of the brain in the form of a mind mapping. Mind mappings are the easiest way to keep information in the form of creative and effective notes so that they are easy to understand. The stages in implementing learning with a mind mapping according to Iis Aprinawati (2018) are (1) learning the concept of a subject matter, (2) determining the main ideas, (3) making a mind mapping, (4) presenting in front of the class.

\section{Method}

This type of research is research and development. The development model used is the 4-D model. Which consists of the stages of defining (define), design (design), development (development), and deployment (disseminate). The results of the research at the defining stage of curriculum analysis and student analysis. The validity analysis used a Likert scale. The Likert scale is a scale that can be used to measure a person's attitudes and opinions about a variable (Riduwan, 2013). According to Arikunto (2013) the Likert scale is prepared with five statements and followed by five responses indicating levels. The performance assessment validity category based on the final score obtained can be seen in Table 1.

Table 1. Product Validity Category

\begin{tabular}{lll}
\hline & Level of achievement & Category \\
\hline$\geq 0,6$ & Valid & \\
\hline$<0,6$ & Invalid & \\
\hline
\end{tabular}

Adopted from: (Azwar, 2015)

To analyze it, a descriptive analysis proposed by Arikunto (2013).With the knowledge competency assessment criteria, it can be seen in the Table

Table 3. Criteria for Ability Competency Assessment

\begin{tabular}{llll}
\hline \multicolumn{1}{c}{ No } & Score & Criteria \\
\hline 1 & $\geq 70$ & & Complete \\
\hline 2 & $<70$ & Not Complete & \\
\hline
\end{tabular}

The developed module can be said as effective if students get a final score of $\geq 70$. 


\section{Results and Discussion}

This development research produced a teaching material in the form of a mind-mapping based mathematics learning module on the opportunity material. The design or module design being developed has been adjusted to the module creation structure which is integrated with mind mapping-based. To get a quality module model, it is necessary to test the validation, practicality, and effectiveness of the module. Validation is very important to determine the quality of the module model before it is tested in learning. In addition, validation is very important to get an assessment of the draft module that has been prepared.

\section{Module Validation}

The validation test of the module aims to check the suitability of $\mathrm{KI}, \mathrm{KD}$, indicators, and correctness of concepts, presentation and grammar in the module. Based on the validity test, the two validators stated that the mathematics learning module was based on a mind mapping on the opportunity material with an average value of $76 \%$ in the valid category.

The module is declared valid after fulfilling 4 aspects, namely didactic aspects, content, presentation, and language. Mind mapping-based mathematics learning module has fulfilled the didactic aspect because the material in the module supports the achievement of basic competencies, mind mapping-based mathematics learning module supports concept understanding, contains images that help students understand the material, modules are in accordance with core competencies and basic competencies in the mathematics learning curriculum. This can be seen in the validity test questionnaire statement on the didactic aspect which has an average value of $73.33 \%$ and is categorized as valid.

In terms of the presentation aspect of the mind mapping-based mathematics module, it is also declared valid because the module has been equipped with titles, core competencies, basic competencies, indicators and learning objectives. In the module presented a mind mapping that explains the learning material clearly, giving the impression that opportunities are not memorizing material, so that it makes students not lazy to read the learning material because the mind mapping explains a simple and clear summary of the material. Not in the form of a long material description that causes students to get bored of reading. Presentation of the material is also equipped with a mind mapping to explain the material discussed. The mind mapping used is clear and attractive and the colors and sizes can be seen properly so that students can understand the learning material well. Mind mappings can help students to remember learning material so that it helps students build knowledge.

In terms of the content aspect, the mind mapping-based mathematics learning module on the opportunity material is declared valid because the module contains mind mapping elements. The presentation of the material in the module is arranged according to a mind mapping.

\section{Practicality Module}

\section{Observation of learning implementation using a mind mapping-based mathematics learning module}

Based on the results of observations of the implementation of learning by using a mind mapping-based mathematics learning module as outlined by the observer in the observation sheet, it is found that the mind mapping-based mathematics learning module can be said to be practical, during learning there are no significant problems. Students are easy to use the module; this can be seen from the few students who questioned the content and appearance / format of the module. The conclusion of the learning process by using a mind mapping-based mathematics learning module can create an atmosphere that encourages students to ask each other, answer and express opinions, the occurrence of interaction between students.

\section{Practical Module by the Teacher}

Based on the results of the practicality trial of the module by the teacher, it shows that the mind mappingbased mathematics learning module on the opportunity material gets a value of $75.3 \%$ indicating that the module is declared practical. This shows that the existence of a mind mapping based mathematics learning module on the opportunity material can make it easier for teachers in the learning process and have an efficient time. Modules can facilitate students to study independently, build their own concepts and find it easier to learn each competency that must be mastered. 


\section{Module Practice by Students}

The results of the module practicality test by students showed an average value of $82.72 \%$ in the very practical category. Thus the average practice of mind mapping-based mathematics learning modules on opportunity material by students is stated to be very practical because the module can increase students' interest in learning. Practical modules are used in the learning process because they help students understand the material about opportunities.

Students feel interested in using a mind mapping-based mathematics learning module because in the module there are clear and easy to understand instructions for use. Inside the module is equipped with a mind mapping that can help students find concepts easily. The module is presented interestingly because the module is presented in color, this can generate interest in students to learn the material in the module because the eyes will focus faster with color.

In addition, learning using a mind mapping-based mathematics learning module raises students' interest in learning mathematics, because the module developed uses language that is easy to understand. This is in accordance with what Bondono expressed in Angela Lia (2014) that using modules with good language helps students understand material more quickly, feel happy, relaxed, and do not feel tense in following learning.

\section{Module Effectiveness Student Activities}

Based on the activity data of 18 students who have participated in the learning process using a mind mappingbased mathematics learning module, it can be seen that the activities of students generally carry out different activities. This shows that students are active in learning and class does not become boring. Student activity during the learning process is one indicator of the student's desire to learn. Student activities observed during the study were reading modules, asking the teacher or other students, listening to the teacher's explanation, doing the exercises in the module, and responding and answering questions orally. The average student activity at the first meeting using a mind mapping-based mathematics learning module on the opportunity material was $70 \%$. The average activity at the second meeting experienced the same increase from the first activity, namely $72.22 \%$ but with a different average indicator. At the third meeting, student activity increased from the previous meeting, namely $81.11 \%$.

\section{Students' Learning Motivation}

From the analysis of the research results showed that for all aspects in the questionnaire motivation were motivated criteria with the average percentage of student motivation in learning was $78.9 \%$. In terms of interest, the average percentage obtained is $80.9 \%$ in the highly motivated category. This means that students have a very high interest in using modules. The high interest of students in learning is because the modules presented are very attractive to students. This is supported by the opinion of Bernand in Sardiman (2011) which states that interest does not arise suddenly, but rather arises as a result of participation, experience, habits during study or work. Therefore, what is important is how to create conditions that arouse student interest in learning, one of which is by using teaching materials in the form of mind mapping-based mathematics learning modules.

In addition, the module is made with a more varied appearance and is equipped with a mind mapping that has a nice and attractive color. With this mind mapping, students are more motivated in learning because previously students only used textbooks in the form of long material descriptions. Students also easily understand the material using the module because the presentation of the material in the module is in accordance with the needs of the students, this can be seen from the results of data analysis which show the relevance of students to the module obtained an average value of $73.8 \%$ with the motivated category. Students also want a lot of other material taught by modules, this can be seen from the results of the data analysis of expectations which show an average score of $86.7 \%$ in the highly motivated category and in terms of satisfaction, the average score of student motivation is 81 ., $9 \%$.

\section{Student learning outcomes}

The learning outcome test is used to determine the effectiveness of the learning process using a mind mappingbased mathematics learning module on the opportunity material. Learning outcomes are abilities that students 
have after they experience their learning experiences. This learning experience is in the form of learning activities that are effective and can realize a variety of learning goals or outcomes. The purpose of assessing teaching and learning outcomes is to measure how far the success rate of the learning process has been implemented.

Based on the test results for the opportunity material for class XI IPA students of SMA Negeri 5 Sungai Penuh data show that out of 18 students who took part in the learning process using the mind mapping-based mathematics learning module, 16 people got more than 70 points. This means $88.89 \%$ of students who achieve score above $75 \%$. Thus learning using a mind mapping-based mathematics learning module can be said to be very successful in achieving students' learning outcomes.

The data shows that there are still 2 students who got score below 70. According to researchers, this failure to graduate is influenced by the ability of students who are still slow to understand the material in the module. They need more time and practice to understand the material in the module. Meanwhile, during the research, the time was only limited to $2 \times 45$ minutes for the learning process using modules for each lesson. The description above shows that the mind mapping-based mathematics learning module developed makes it easier for students to understand the learning material, so that students' learning outcomes become more optimal.

\section{Conclusion}

Based on the results of the research conducted, the following conclusions were obtained: 1) The mind mapping based mathematics learning module on the opportunity material that has been developed has validation with a valid category with an average value of $76 \%$ in the valid category. The module is said to be valid after fulfilling 4 aspects, namely inactive aspects, content aspects, presentation aspects, and language aspects; 2) The mind mapping based mathematics learning module on the opportunity material that has been developed has practicality with a practical category with an average value of $75.3 \%$. This shows that the existence of a mind mapping-based mathematics learning module on the opportunity material can make it easier for teachers in the learning process and have an efficient time. Modules can facilitate students to study independently, develop their own concepts and find it easier to learn each competency that must be mastered; 3) Mind mapping-based mathematics learning module on the opportunity material that has been developed has effectiveness with the effective category in terms of activity aspects, students' motivation, and from the aspect of achieving learning outcomes.

\section{References}

Abidin, Yunus. 2014. Desain Sistem Pembelajaran dalam Konteks Kurikulum 2013. Bandung: Refika Aditama

Andi Prastowo. 2011. Metode Penelitian Kualitatif dalam Perspektif Rancangan Penelitian. Jogjakarta: Ar-Ruzz Media.

Anita lie. 2014. Cooperative Learning. Jakarta: Grasindo

Anwar, Ilham. 2013. Pengembangan Bahan Ajar. Bahan Kuliah Online. Direktori UPI. Bandung

Asyhar, Rayandra. 2013. Kreatif Mengembangkan Media Pembelajaran. Jambi:Referensi

Azwar, Saiffuddin. 2013. Reliabilitas dan Validitas. Yogyakarta: Pustaka Pelajar.

Brog and Gall. 1979. Educational Research: An Introduction. Jurnal New York \& London: Longman. Vol. 3, (Diakses 5 Juli 2019)

Direktorat Pembinaan Sekolah Menengah Atas. 2010. Pedoman Penyusunan Bahan Ajar. Jakarta: Lukmana, Direktorat Pembinaan Sekolah Menengah Atas.

Endang Novita Tjiptiany, Abdur Rahman As'ari, Makbul Muksar. 2014. Pengembangan Modul Pembelajaran Matematika dengan Pendekatan Inkuiri untuk Membantu Siswa SMA Kelas X dalam Memahami Materi Peluang. Jurnal Pendidikan: Teori, Penelitian dan Pengembangan. Vol. 1 (10) Hal 1938-1942.

Gunawan. 2013. Genius Learning Strategy. Jakarta: Gramedia Pustaka Umum

Hosnan. 2014. Pendekatan Saintifik dan kontekstual dalam Pembelajaran Abad 21. Bandung. Ghalia Indonesia Iis Aprinawati. 2018. Penggunaan Model Peta Pikiran (Mind Mapping) untuk Meningkatkan Pemahaman Membaca Wacana Siswa Sekolah Dasar. Vol 2(1) hal. 140-147. 
Koesnandar. (2018). Pengembangan Bahan Ajar Berbasis Web. [Online] tersedia di http://www.teknologipendidikan.net accessed on August 01, 2020.

Pannen, Paulina, dkk. 2011. Kontruktivisme dalam Pembelajaran. Jakarta: Depdiknas

Rahdiyanta, Dwi. 2013. Teknik Penyusunan Modul. UNY

Riduwan, Sunarto. 2012. Pengantar Statistika. Bandung: ALFABETA.

Sugiyono. 2013. Metode Penelitian Kuantitatif Kualitatif dan R\&D. Bandung: ALFABETA

Suharsimi Arikunto. 2013. Prosedur Penelitian. Jakarta: PT. Rineka Cipta

Sutrisno. 2011. Pengantar Pembelajaran Inovatif Berbasis Teknologi Informasi dan Komunikasi. Jambi: GP Pres

Trianto. 2013. Mendesain Model Pembelajaran Inovatif-Progresif : Konsep, Landasan, dan Implementasinya pada Kurikulum Tingkat Satuan Pendidikan (KTSP). Jakarta: Kencana Prenada Media Group.

Undang-Undang RI Nomor 20 Tahun 2003 Tentang Sistem Pendidikan Nasional. Jakarta: BNSP

Widura, S. 2013. Mind Map untuk Siswa, Guru dan Orang Tua. Jakarta: Gramedia

Widyastuti Susana. 2013. Metode Belajar Efektif. Klaten. Pusat Pengembangan Anak Wijaya, Cece,.dkk. 1988. Upaya Pembaharuan Dalam Pendidikan dan Pengajaran. Bandung: Remadja Karya.

Winkel. 2019. Psikologi Pengajaran. Yogyakarta: Media Abadi 